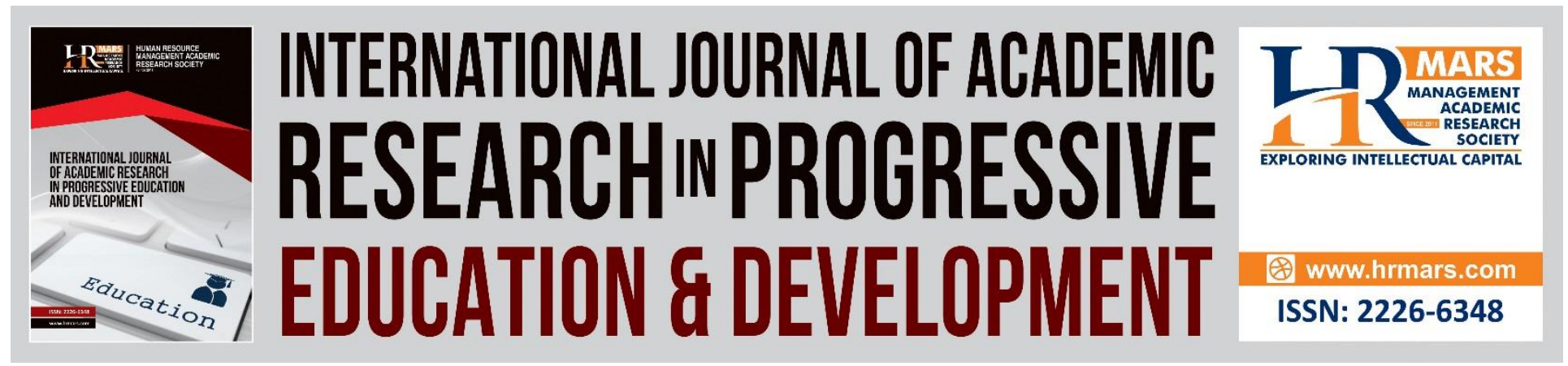

\title{
Parental Involvement in Discipline Management of Special Education Students in Schools
}

Norshidah Mohamad Salleh, Fatin Nabihah Rosli

To Link this Article: http://dx.doi.org/10.6007/IJARPED/v8-i4/6781

DOI:10.6007/IJARPED/v8-i4/6781

Received: 18 October 2019, Revised: 22 November 2019, Accepted: 11 December 2019

Published Online: 30 December 2019

In-Text Citation: (Salleh \& Rosli, 2019)

To Cite this Article: Salleh, N. M., \& Rosli, F. N. (2019). Parental Involvement in Discipline Management of Special Education Students in Schools. International Journal of Academic Research in Progressive Education and Development, 8(4), 912-920.

Copyright: (C) 2019 The Author(s)

Published by Human Resource Management Academic Research Society (www.hrmars.com)

This article is published under the Creative Commons Attribution (CC BY 4.0) license. Anyone may reproduce, distribute, translate and create derivative works of this article (for both commercial and non-commercial purposes), subject to full attribution to the original publication and authors. The full terms of this license may be seen

at: http://creativecommons.org/licences/by/4.0/legalcode

Vol. 8(4) 2019, Pg. $912-920$

http://hrmars.com/index.php/pages/detail/IJARPED

JOURNAL HOMEPAGE

Full Terms \& Conditions of access and use can be found at http://hrmars.com/index.php/pages/detail/publication-ethics 


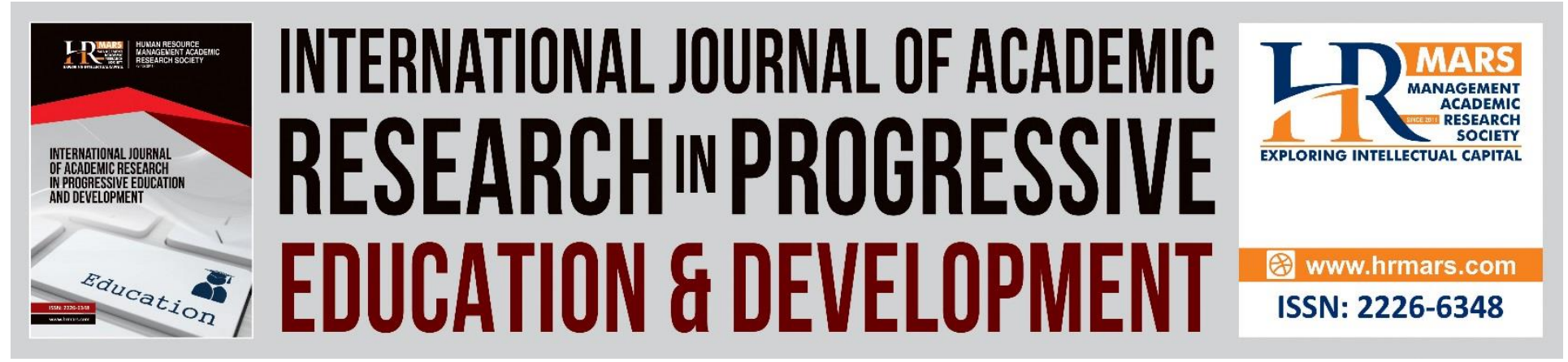

\title{
Parental Involvement in Discipline Management of Special Education Students in Schools
}

\author{
Norshidah Mohamad Salleh, Fatin Nabihah Rosli \\ Universiti Kebangsaan Malaysia, Malaysia \\ Email: nshidah@ukm.edu.my
}

\begin{abstract}
This working paper discusses research findings related to parental involvement in the management of discipline among special education children in schools. Its two specific objectives are identifying in this research; the forms of involvement and the obstacles faced by parents. Quantitative research was conducted in survey manner on parents of special needs children in 11 primary schools from a state in Peninsular Malaysia, namely Negeri Sembilan. The research instrument used was questionnaire that was adapted from the questionnaire Family Involvement Study High School. The study sample consisted of 110 parents selected through Purposive Sampling, whereby all parents were identified as having learning difficulty children in primary schools in Negeri Sembilan. Data was analyzed descriptively using SPSS to obtain Mean Values and Standard Deviation. Research findings indicate that the overall involvement of parents in discipline management of special education students was at a moderate level (mean = 3.66). Out of the six forms of parental involvement, the role of parents (mean $=3.90$ ) and study support at home (mean $=4.06$ ) occupied top spots. Meanwhile obstruction to parental involvement in discipline management in schools was also at moderate level (mean $=3.20$ ), where in five of the obstacles were at moderate levels. Socioeconomic standard, however was not a primary obstacle, and was at a low level (mean $=2.58$ ). Thus, problems encountered by these parents need to be handled so that parental involvement with regards to their children's discipline management can be elevated to a higher level. The implication of this study speaks of the need by school authorities to reduce resistance faced by parents so that they can involve themselves in all activities and programs that are carried out by school. Through the cooperation forged between teachers and parents, misconduct and discipline problems of students can be handled collectively by both school and parents.
\end{abstract}

Keywords: Parental Involvement, Discipline Management, Special Education Students, and Obstacles to Involvement

\section{Introduction}

The issue of misconduct or disciplinary problems has received extensive coverage from the mass media and has been hotly debated as this seems to be a never-ending problem. Various measures 
have been taken by the Malaysian Ministry of Education (MME) to handle this issue, including preparing guidelines, tightening rules, and implementing merit systems in order to curb disciplinary cases from escalating. This is in line with efforts to form high quality human capital and noble character, as expounded in the National Education Philosophy. Since 1957, through the Education Ordinance and Schools Disciplinary Regulations 1959, MME has prepared guidelines for implementation of discipline that can be utilized in all schools in Malaysia. One of the critical aspects in handling the problem of misconduct in schools is by means of discipline management, that is the ability to carry out each regulation procedure that has been defined or outlined as being compulsory, for purposes of creating a safe environment and create virtuous characters (Kementerian Pendidikan Malaysia, 1988; Khalim, 2014; Jusoh, Salleh, Embong, \& Mamat, 2018: Wicaksana \& Asandimitra, 2018). The MME has outlined regulations, produced guidebooks and issued professional circulars as primary references for school administrators, teachers and parents for handling disciplinary problems in schools. In the event that this misconduct is not controlled and handled properly, it can lead to even bigger problems of discipline, including social ills (Zainudin \& Norazmah, 2011), bullying (Norshidah \& Khalim, 2014), smoking (Azizi, Shahrin \& Mascilla, 2012) and many other undesirable forms of behavior. As such, the management of students' discipline in school needs to be done with full commitment by all parties concerned including administrators, teachers and parents.

\section{Literature Review}

Special education students often display disturbing and challenging behavior (Joslyn, Vollmer, \& Hernández, 2014). Although this behavior can be reduced by the method of Good Behavior Game, the giving out of incentives, and molding of good behavior, research by Donaldson, Wiskow \& Soto (2015), shows that problematic behaviour is unable to be remedied fully. Meanwhile another research (Boaduo, Milondzo \& Adjei, 2009), pointed out that involvement of school and teachers, along with parents and the community clearly has a marked effect towards positive behavior and achievement of students. This demonstrates that the misbehavior of these problematic students is not capable of being managed solely by school administrators, as parents can also play a key role in assisting school authorities handling this problem among special education students.

According to McCormick, Cappella, O'Connor \& McClowry, (2013), the role and involvement of parents in helping resolve disciplinary problems of special education students, such as disruptive behavior and challenging behavior, still have not received much attention. The importance of parental involvement in children's education has frequently been debated; Centre for Child Well Being (2012) explains that parental involvement can encourage the learning and development of children. The involvement of parents too, can boost good behaviour amongst school children and reduce absenteeism (Sapungan \& Sapungan, 2014; Malukeke, 2014). Therefore, this shows that the involvement of parents has led to an improved level of behavior among students.

To bolster discipline management of students in school, the MME, through its Professional Circular Letter No. 8/2001 has emphasized the importance of parent's involvement in managing discipline in schools (Kementerian Pendidikan Malaysia, 2001). To ensure its success, parents have been asked to provide cooperation by giving information, and not keeping problems faced by the children under wraps. Providing information regarding unusual behavior of students 
would facilitate school administrators to take the necessary actions in a collaborative manner with the parents. If the problem of misconduct among students is not handled immediately, it would disrupt the teaching and learning process in the classroom.

However, in efforts to bring about cooperation between school and parents, there are numerous barriers when it comes to the involvement of parents in school. Among these problems include the perception among some parents that the responsibility of educating students lies squarely on the shoulders of school authorities. Besides that, certain parents also exhibit negative perceptions towards teachers and school (Murray, Finigan, Jones, Copeland-Linder, Haynie, \& Cheng, 2014). There are also cases where parents are just not interested to be involved in helping resolve disciplinary problems of their children at school. Research by LaRocque, Kleiman \& Darling (2011), provides information that points out that the majority of parents are not aware of their rights to be involved in school activities, and have low parenting skills. These factors regarding parents prove to be obstacles as they have low self-confidence and feel that they are not important as far as helping school manage their children's discipline problems is concerned. Other than the attitude of parents, the attitude of school and teachers also presents hindrances to parents involving themselves in school activities. According to Kim (2009), school administrators often feel that parental involvement does not bring any benefit or effect to the school. This is because parents are quite busy with other affairs and are quite restricted in terms of allocating time for involving themselves in schools. Parents find it difficult to get leave, have work schedules that are constantly changing, and they also have to attend to the task of managing household chores (Archer-Banks \& Behar-Horenstein 2008; Velsor \& Orozco, 2007). Parents do not have the time to come to school and discuss arising problems and to update themselves regarding the problems faced by their children. Due to this, school administrators feel that they can manage matters related to students better on their own without the help of parents. One other obstacle in the involvement of parents is that schools seldom invite parents to participate in activities carried out in schools (Murray et al. 2014). This attitude denies the role and involvement of parents in helping handle the problem of student indiscipline. The lack of clear communication between teachers and parents also widens the gap in the involvement of parents in student discipline management in schools (Sheldon, 2002). Hence, this study was conducted to probe the involvement of parents in discipline management of special education students in schools. This working paper discusses two research questions:

1. What is the form of parental involvement?

2. What are obstacles faced by parents?

\section{Methodology}

This is a quantitative study using survey method. The study sample comprised 110 parents of learning difficulty students in primary schools in Negeri Sembilan, one state in Peninsular Malaysia. Purposive Sampling method was employed as the number of parents was limited due to specific requirement factors that had been predetermined in order to procure the necessary information, in that they had to be parents of special educational needs children. Research instrument utilized was questionnaire adapted from Family Involvement Study High School (Grove, 2015) questionnaire, in order to collect research data. The questionnaire was divided into two sections; forms of parental involvement, and obstacles to parental involvement. The 
Vol. 8, No. 4, 2019, E-ISSN: 2226-6348 @ 2019 HRMARS

questionnaire used a 5-point Likert scale. Analysis of pilot study results showed that research instruments had a high alpha reliability value, with Cronbach value of 0.981 . Data analysis was by means of descriptive SPSS (Statistical Package of Science for Windows) software in order to obtain the Mean Value and Standard Deviation.

\section{Research Findings}

a. Forms of parental involvement in discipline management of special education students

Table 1: Mean Value and Standard Deviation of forms of parental involvement in special education students' discipline management

\begin{tabular}{llll}
\hline & Mean & \multicolumn{2}{l}{$\begin{array}{l}\text { Standard } \\
\text { Deviation }\end{array}$} \\
\hline Role of parents & 3.90 & 0.68 & High \\
Household-School Communication & 3.56 & 0.87 & Moderate \\
Volunteerism & 3.33 & 0.91 & Moderate \\
Learning at home & 4.06 & 0.50 & High \\
Mutual decisions & 3.53 & 0.95 & Moderate \\
Collaboration with Community & 3.56 & 0.85 & Moderate \\
\hline Overall Involvement & $\mathbf{3 . 6 6}$ & $\mathbf{0 . 6 2}$ & Moderate \\
\hline
\end{tabular}

(Levels: Low $=1.00-2.33$, Moderate $=2.34-3.66$, High $=3.67-5.00$ )

The table above shows research findings of parental involvement in discipline management of special education students that was measured using six dimensions; Role of Parents, HouseholdSchool Communication, Volunteerism, Learning at Home, Mutual Decisions, and Collaboration with Community. Overall, research findings indicate that parental involvement in discipline management of special education students was at a moderate level (mean $=3.66, \mathrm{SD}=0.62$ ). Meanwhile the high scores were for Role of Parents (mean $=3.90, \mathrm{SD}=0.68$ ), and Learning at Home (mean $=4.06, S D=0.50)$. As for Volunteerism, it registered the lowest score (mean $=3.33$, $\mathrm{SD}=0.91$ ) as a form of involvement, however, it was still at a moderate level.

b. Obstacles to parental involvement in discipline management of special education students Research findings of obstacles to parental involvement in discipline management of special education students was measured in six dimensions as well; Parents' Knowledge, School Authorities, Time, Communication, Socioeconomic Level, and finally, Parents' Attitude. Table 2 depicts that the overall score (mean $=3.20, S D=0.99$ ) for obstacles to parental involvement in discipline management of special education students was at a moderate level, with the score for all six dimensions of obstacles also being at a moderate level. The obstacle of time (mean $=3.56$, $S D=1.07$ ) was highest for the involvement of parents. This was followed by the obstacle of school authorities (mean $=3.43, \mathrm{SD}=1.27$ ), Communication ( mean $=3.41, \mathrm{SD}=1.12$ ), Parents' Attitude (mean $=3.38, \mathrm{SD}=1.13)$ and Knowledge $($ mean $=2.82, \mathrm{SD}=1.21)$. As for Socioeconomic Level ( mean $=2.58, \mathrm{SD}=1.19)$, this was not a significant obstacle towards the involvement of parents in discipline management of special education students. 
INTERNATIONAL JOURNAL OF ACADEMIC RESEARCH IN PROGRESSIVE EDUCATION AND DEVELOPMENT

Vol. 8, No. 4, 2019, E-ISSN: 2226-6348 @ 2019 HRMARS

Table 2: Mean Value and Standard Deviation of Obstacles to Parental Involvement in Discipline Management of Special Education Students

\begin{tabular}{llll}
\hline & Mean & $\begin{array}{l}\text { Standard } \\
\text { Deviation }\end{array}$ & Level \\
\hline Knowledge & 2.82 & 1.21 & Moderate \\
School Authorities & 3.43 & 1.27 & Moderate \\
Time & 3.56 & 1.07 & Moderate \\
Communication & 3.41 & 1.12 & Moderate \\
Socioeconomic Level & 2.58 & 1.19 & Moderate \\
Parents' Attitude & 3.38 & 1.13 & Moderate \\
\hline Overall Obstacles & $\mathbf{3 . 2 0}$ & $\mathbf{0 . 9 9}$ & Moderate \\
\hline
\end{tabular}

(Level: Low $=1.00-2.33$, Moderate $=2.34-3.66$, High $=3.67-5.00$ )

\section{Discussion}

This research paper discusses research findings of forms of involvement, and also the obstacles to parental involvement in discipline management of special education students. Research findings show that most parents were carrying out their parental roles and responsibilities in making preparations for their children's' schooling needs, such as providing proper uniforms, books, stationery as well as arranging transport to and from school. Parents are aware of their roles as parents by means of their own initiatives and also by attending parenting workshops arranged by schools and by other organizations. The awareness of the importance of these courses and information regarding parenting can help parents upgrade their knowledge and skills to teach and manage their children in a better and appropriate manner (Cavkaytar, 2007). Parents also have the role to prepare conducive environment at home for their children to study so that they can manage to complete their homework (LeFevre \& Shaw, 2012). Comfortable environment and study spaces would motivate students to revise their lessons. Parents involved in assisting their children to complete their homework can upgrade students' achievement levels (Aida \& Zolkepli, 2014; Manisah, Azleen, Norshidah \& Majid, 2017). The continuity of learning in school and at home, not only helps in academic attainment but also helps remedy problematic behavior among students (Norshidah \& Khalim, 2018).

Research findings also illustrate that time constraint is the main obstacle faced by parents in involving themselves in discipline management of their special children. The issue of time constraint stems from a variety of reasons such as managing family chores, work demands, difficulty in getting leave, constantly changing work schedules, and there are also parents who hold more than one job (Velsor \& Orozco, 2007). These constraints cause them not to be able to have time to be involved in activities and programs organized by school (Murray et.al, 2014). The problems encountered by parents make it challenging for them to focus on their special children or getting involved in the various activities arranged by the school.

The second most significant obstacle in this research is the attitude of school administrations, with regards to parental involvement. According to Kim (2009), parents feel school administrations do not try to attract their participation in Parent's Teacher Association (PTA) meetings as they feel that parents' services are not needed in schools. Cooperation between parents and school can be initiated through PTA meetings by having exchange of ideas, sharing 
of problems and seeking viable solutions to manage of student indiscipline. School administrations need to be more open and make efforts to attract parents' participation so that both parties can together take part in handling the discipline problems of special needs children. Communication between parents and schools needs to be enhanced. This is because communication is an important medium to ensure positive discussion and close cooperation between parents and school. According to Timberly, Gwendolyn \& Skiba (2016), the source for the weakness in communication is due to the ignorance of parents of the best ways to communicate with school administrations. This failure to communicate leads to parents not having information from schools about their children. Multiple approaches can be taken by school to overcome this obstacle; by sharing information with parents via telephone, Whatsapp, e-mail, facebook, daily notes and note books. Teachers also must be more open to receiving ideas and viewpoints from parents. The school should welcome the presence of parents in schools so that they feel that their presence is valued, thus encouraging them to participate more actively in school activities, PTA meetings and Individual Education Programs (IEP). Two-way direct communication can help eliminate misperception and suspicion between these two parties.

\section{Conclusion}

Results of this study have provided information regarding the involvement of parents in discipline management of their special needs children in school. To encourage involvement and participation of parents, obstacles that exist between parents and teachers need to be resolved by both parties. By means of the ensuing cooperation and and understanding, the disciplinary problems of students can thus be handled together. This integration and continuity between school and home would greatly increase the likelihood of overcoming problems faced by students and consequently lead to enhanced academic achievements.

\section{Acknowledgment}

This research was supported by the grant from the Faculty of Education, Universiti Kebangsaan Malaysia: GG-2019-003

\section{References}

Archer-Banks, D. A. M., \& Behar-Horenstein, L. S. (2008). African American parental involvement in their children's middle school experiences. Journal of Negro Education. 77, 143-156.

Azizi, Y., Shahrin, H., \& Mascilla, H. (2012). Masalah salah laku agresif dalam kalangan pelajar sekolah rendah dan hubungannya dengan gaya keibubapaan. Jurnal Teknologi (Social Sciences). 58, 91-10.

Boaduo, N. A. P., Milondzo, K. S., \& Adjei, A. ( 2009. Parent-community involvement in school governance and its effects on teacher effectiveness and improvement of learner performance: A study of selected primary and secondary schools in Botswana. Educational Research Review, 4(3), 96-105.

Cavkaytar, A. (2007). Turkish parents as teachers: Teaching parents how to teach self-care and domestic skills to their children with mental retardation. Education and Training in Developmental Disabilities, 42(1), 85-93. 
Centre for Child Well Being, (2012). Importance of Parental Involment in Their Children's Learning. Retrieved from http://www.mtroyal.ca/ wellbeing

Deslandes, R. \& Bertrand, R. (2005). Motivation of parent involvement in secondary-level schooling. The Journal of Educational Research. 98, 164-174.

Donaldson, J. M., Wiskow, K. M., \& Soto, P. L. (2015). Immediate and distal effects of the good behavior game. Journal of Applied Behavior Analysis. 48, 685-689 http://onlinelibrary.wiley.com/doi/10.1002/jaba.229/full. [25 April 2019].

Grover, K. N. (2015). A Validation of the Family Involvement Questionnaire-High School Version. Minnesota State University - Mankato

Joslyn, P. R., Vollmer, T. R., \& Hernandez, H. (2014). Implementation of the good behavior game in classrooms for the children with delinquent behavior. Acta De Investigacion Psicologica. 4(3), 1673-1681. http://www.sciencedirect.com/science/article/pii/S2007471914709731.[25 April 2019].

Jusoh, A., Salleh, M., Embong, R., \& Mamat, M. (2018). The Influence of Mathematical Teacher Competency on Creative Teaching Practice. International Journal of Academic Research in Progressive Education and Development, 7(4), 397-409.

Kementerian Pelajaran Malaysia. (1959). Peraturan-peraturan Pelajaran (Disiplin Sekolah) 1959. Kuala Lumpur: KPM

Kementerian Pendidikan Malaysia. (1988). Panduan tatacara disiplin sekolah untuk guru besar dan guru. Kuala Lumpur: Dewan Bahasa dan Pustaka.

Kementerian Pelajaran Malaysia. (2001) Surat Pekeliling Ikhtisas Bil.8/2001: Pemantapan Pengurusan Disiplin Di Sekolah.

Khalim, Z. (2014). Pengurusan disiplin pelajar sekolah. Bangi: Penerbit Universiti Kebangsaan Malaysia.

Kim, Y. (2009). Minority parental involvement and school barriers: Moving the focus away from deficiencies of parents. Educational Research Review. 4, 80-102.

LaRocque, M., Kleiman, I., \& Darling, S. M. (2011). Parental Involvement: The Missing Link in School Achievement. Preventing School Failure: Alternative Education for Children and Youth, 55(3), 115-122.

LeFevre, A. L., \& Shaw, T. V. (2012). Latino parent involvement and school success: Longitudinal effects of formal and informal support. Education and Urban Society, 44, 707-723.

Malukeke, S. G. (2014) Parental Involvement in Their Children Education in the Vhembe District Limpopo, University of South Africa, Pretoria. Retrieved from http://hdl.handle.net/10500/18814

Manisah, M. A., Azleen, M. B., Norshidah, M. S., \& Rosadah, A. M. (2017). Perceived fathers` acceptance on Malaysian children with special needs. Asia-Pacific Journal of Intellectual Disabilities. 4(2), 12-20.

McCormick, M. P., Cappella, E., O’Connor, E. E., \& McClowry, S. G. (2013). Parent involvement, emotional support, and behavior problems: An ecological approach. The Elementary School Journal. 114(2), 277-300.

Murray, K. W., Finigan, N., Jones, V., Copeland-Linder, N., Haynie, D. L., \& Cheng, T. L. (2014), Barriers and facilitators to school-based parent involvement for parents of urban public middle school students. SAGE open. 4(4), 1-12. 
Norshidah, N. M., \& Khalim, Z. (2014) Bullying Among Secondary School Students in Malaysia: A Case Study. International Education Studies. 7(13), 184-190. https://dx.doi.org:10.5539/ies.v7n13p184

Norshidah, N. M., \& Khalim, Z. (2018). Instructional model for social skills imtervention children with visual impairment. Creative Education, 9, 2325-2333. https://doi.org/10.4236/ce.2018.914172

Sheldon, S. B. (2002). Parents' social networks and beliefs as pre- dictors of parent involvement. The Elementary School Journal. 102, 301-316.

Sapungan, G. M., \& Sapungan, R. M. (2014). Parental Involment in Child's Education: Importance, Barriers and Benefits. Asian Journal of Management Science and Education.

Timberly, L. B., Jillian, W., Gwendolyn, K., \& Skiba, R. J. (2016). Identifying Barriers: Creating Solutions to Improve Family Engagement. School Community Journal. 26(2), 161-184.

Velsor, V. P., \& Orozco, G. L. (2007). Involving low-income parents in the schools: Community centric strategies for school counselors. Professional School Counseling. 11, 17-24.

Wicaksana, S.B., Asandimitra, N. (2018). Halloween Effect in Indonesia Stock Exchange, International Journal of Academic Research in Accounting, Finance and Management Sciences 8 (3): 118-127

Zainudin, S., \& Norazmah, M. R. (2011). Faktor-faktor yang mempengaruhi remaja terlibat dalam masalah sosial di Sekolah Tunas Bakti, Sungai Lereh, Melaka. Journal of Education Psychology \& Counseling. 1(7), 115-140. 